\title{
Site Selection for Weihai Port International Logistics Center Based on Centroid Method and Fuzzy Evaluation Method
}

\author{
Min Liu ${ }^{1}$, Xingqi Fan', QiangTian ${ }^{1}$, Jialei Zhan ${ }^{2}$ \\ ${ }^{I}$ Yantai NanshanUniversity, China \\ ${ }^{2}$ Nanshan Group, Yantai 265713, Shandong, China
}

\begin{abstract}
Centroid method is used to study siteselection forWeihai Port International Logistics Center, then relevant index system is built based on the factors influencing site selection.Fuzzy comprehensive evaluation method is used to score several locations in Weihai City so that the optimal location can be selected via comparison. The research conclusions have a certain reference value for the site selection of Weihai comprehensive international logistics distribution center, which carries positive significance for the development of international logistics industry in Weihai Port and the urban area.
\end{abstract}

Keywords: Weihai Port, logistics center, site selection

\section{Basic Information about Weihai Port}

As one of China's excellent harbors with a century-old history, Weihai Port stands out for its unique geographical location since its establishment. In 2017, Weihai Port Group completed a cargo throughput of 44.675 million tons and made a profit of 191 million yuan. According to the "Communiqué" issued by the Ministry of Communications in 2018, the annual port cargo throughput of Weihai Port was 55,696,200 tons. On August 6, 2019, Shandong Port Group was inaugurated and established. With it, Qingdao Port and Weihai Port achieved integrated development. As of December 28 of that year, the container throughput of Weihai Port exceeded 21 million TEUs and the throughput of general cargo exceeded 40 million tons. In recent years, under the support of national strategies such as China-South Korea Free Trade Zone and the "Belt and Road Initiative", the foreign trade volume has increased year by year, displaying a rapid growth trend [1-3].

\section{Site Selection Design for Weihai Port International Logistics Center based on Centroid Method}

2.1 Construction of centroid model

Suppose there are $n$ goods demand points, whose respective coordinates are $\left(x_{j}, y_{j}\right)(j=1, \cdots, n)$. Logistics facility coordinates are $(x, y) . h_{j}$ is the delivery rate from the logistics facility to the demand point $j$ (that is, the delivery fee per ton-kilometer), $\omega_{j}$ is the delivery volume from the logistics facility to the demand point $j$. The centroid model is shown in Figure 1.

ISSN: 0010-8189 


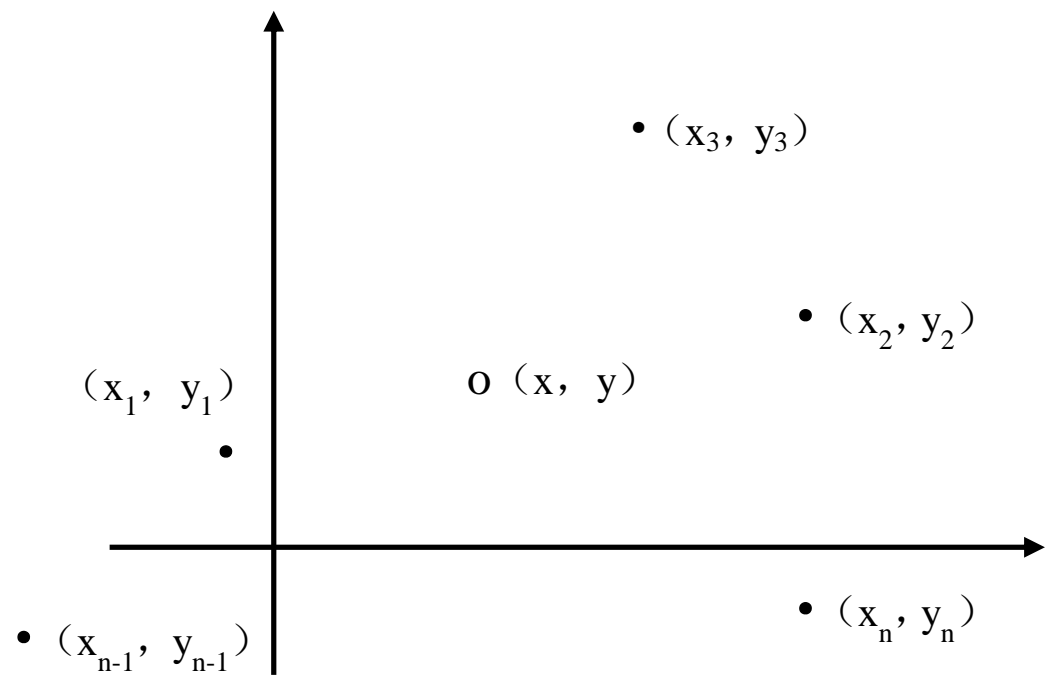

Fig 1: Simplified diagram of the centroid model

According to the method of calculating the centroid of the object system in the plane, there is

$$
\left\{\begin{array}{l}
x \cdot \sum_{j=1}^{n} h_{j} \omega_{j}=\sum_{j=1}^{n} h_{j} \omega_{j} x_{j} \\
y \cdot \sum_{j=1}^{n} h_{j} \omega_{j}=\sum_{j=1}^{n} h_{j} \omega_{j} y_{j}
\end{array}\right.
$$

Sort it, then

$$
\left\{\begin{array}{l}
x=\sum_{j=1}^{n} h_{j} \omega_{j} x_{j} / \sum_{j=1}^{n} h_{j} \omega_{j} \\
y=\sum_{j=1}^{n} h_{j} \omega_{j} y_{j} / \sum_{j=1}^{n} h_{j} \omega_{j}
\end{array}\right.
$$

According to the above formula, the location $(x, y)$ of the logistics facility can be calculated. In addition, let $C_{j}$ be the freight from the logistics facility to each demand point, then the total freight is expressed as

$$
H=\sum_{j=1}^{n} C_{j}
$$

$\mathrm{C}_{\mathrm{j}}$ can be expressed by the following formula 


$$
C_{j}=h_{j} \times \omega_{j} \times d_{j}
$$

Thus,

$$
H=\sum_{j=1}^{n} h_{j} \omega_{j} d_{j}
$$

Where, $\mathrm{h}_{\mathrm{j}}$ - the delivery rate from the logistics facility to the demand point $\mathrm{j}$ (that is, the delivery fee per ton-kilometer);

$\omega_{\mathrm{j}}$ the demand at demand point $\mathrm{j}$;

$\mathrm{d}_{\mathrm{j}}$ - the distance from the logistics facility to the demand point $\mathrm{j}$.

\subsection{Site selection process based on the centroid model}

Considering the lack of international logistics park in Weihai City, we made data analysis based on small logistics distribution centers and express delivery centers relevant with international trade in Weihai, and intend to build an international logistics center based on centroid method. TakeWeihaiHigh-tech Zone Logistics Distribution Center as the research object, and its transportation (demand) status in the surrounding area is shown in Figure 2[4-6].

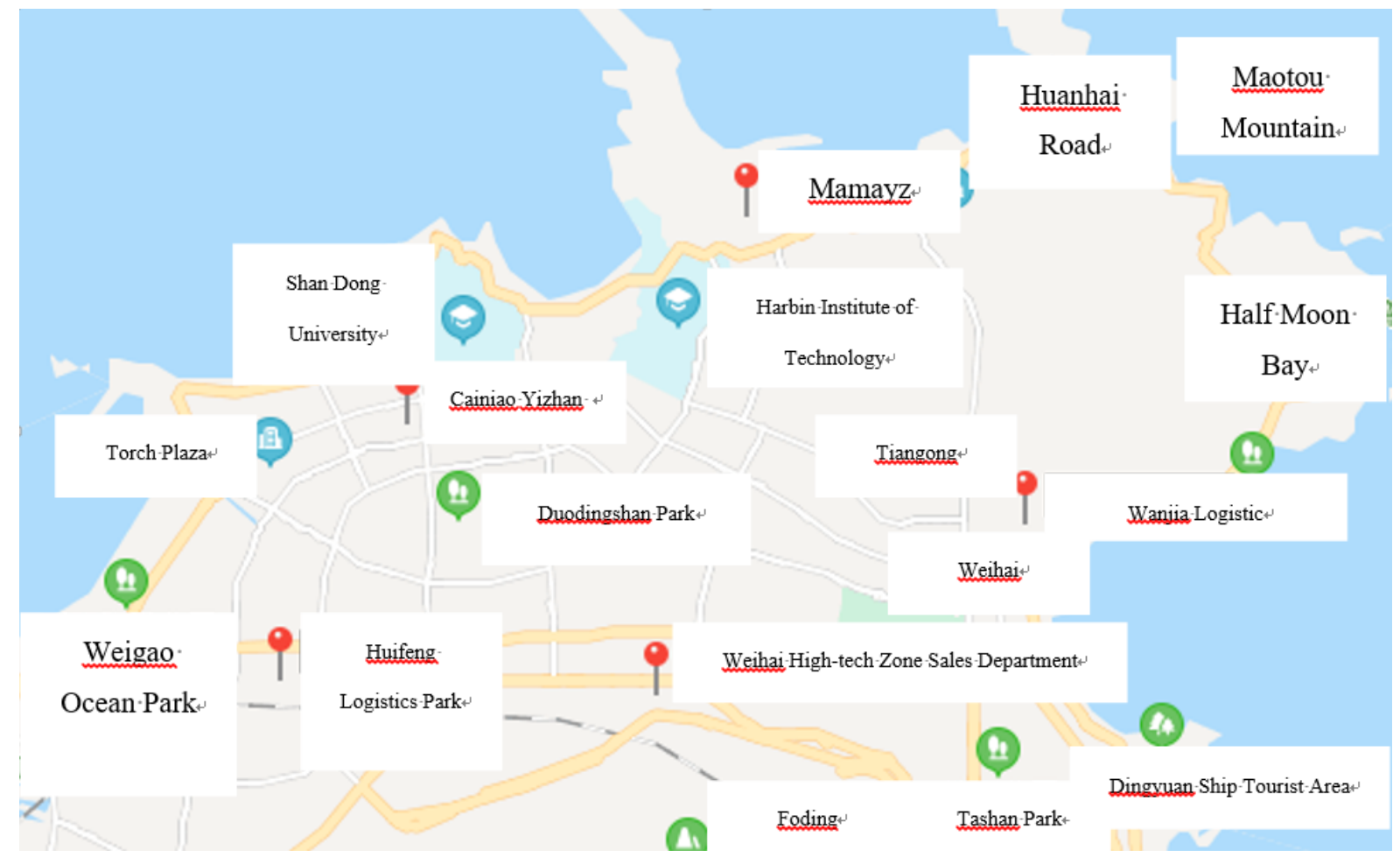

Fig 2: Some small and medium-sized logistics distribution centers in Weihai High-tech Zone

Huifeng Logistics Park, Weihai High-Tech Zone Sales Department, Wanjia Logistics Weihai Branch, Harbin Institute of Technology (Weihai) Mamayz, and Shandong University (Weihai) CainiaoYizhan, which have direct international trade relations with Weihai Port in High-Tech Zone, are respectively denoted as A, B, C, D, and E. The five places are marked on the coordinate axis as shown in Figure 3. 


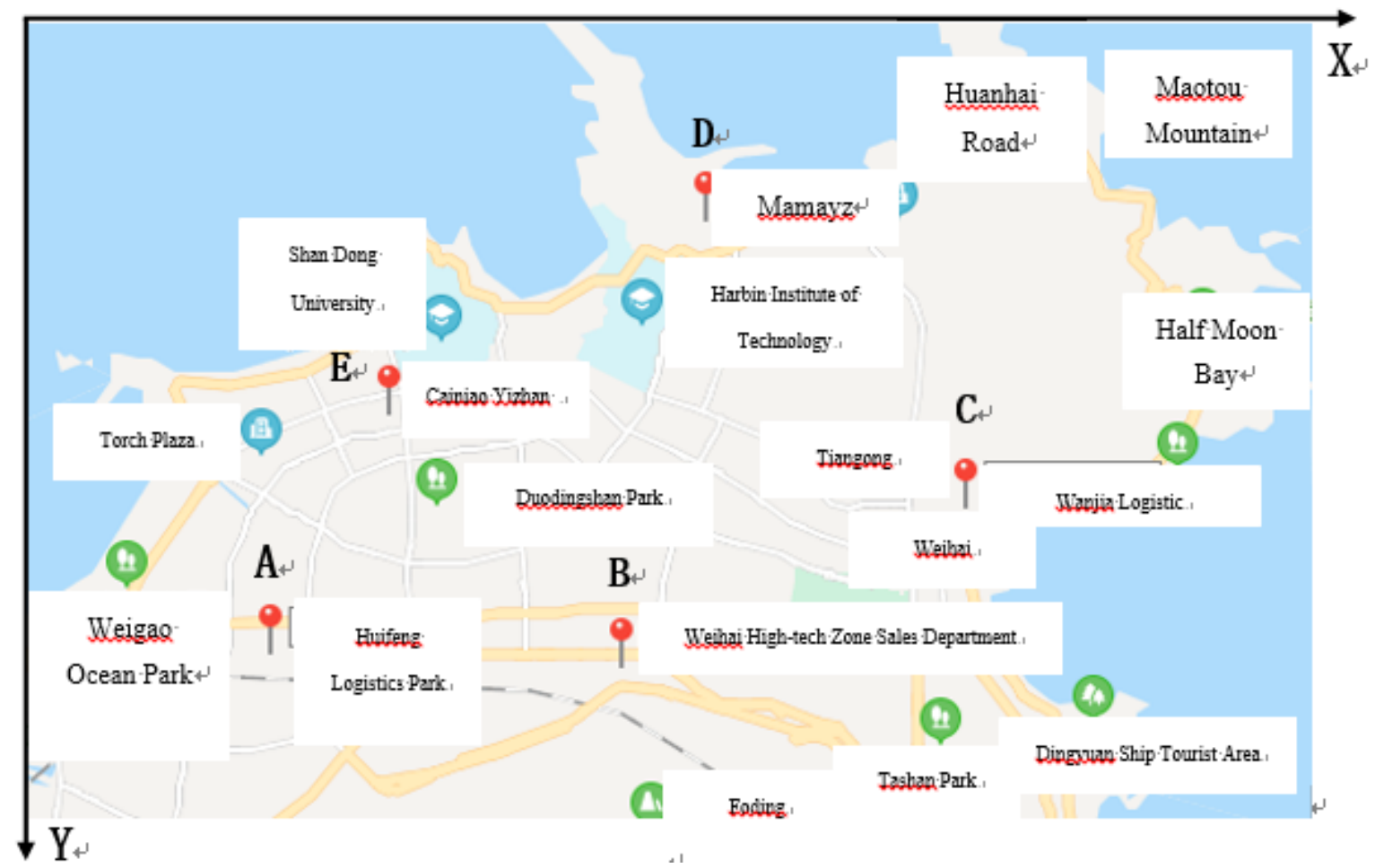

Mamayz,CainiaoYizhan,Huifeng Logistics Park,WeihaiHigh-tech Zone Sales Department,Wanjia Logistics Fig 3: Coordinate axis establishment

After analysis and collection, the information of the five demand points (supply points) is shown in Table 1.

Table 1 Demand point data table

\begin{tabular}{ccccc}
\hline Node & X coordinate & Y coordinate & $\begin{array}{c}\text { Freight } \\
\text { volume } \omega_{j}\end{array}$ & Rate $h_{j}$ \\
\hline A & 0.35 & 7.71 & 2500 & 0.6 \\
B & 5.35 & 8.25 & 2000 & 0.5 \\
C & 11.62 & 6.05 & 1800 & 0.4 \\
D & 7.44 & 0.79 & 1000 & 0.8 \\
E & 2.70 & 3.03 & 1000 & 0.7
\end{tabular}

Note: The data mainly derives from the statistics of import and export freight volume on the official website of Weihai Port International Trade Company.

Suppose the newly-built distribution center is $\mathrm{O}$, the corresponding location coordinates are (a,b), and the demand point is $\left(x_{j}, y_{j}\right)(j=1,2, \ldots 5)$.From 


$$
\left\{\begin{array}{l}
x=\sum_{j=1}^{5} h_{j} \omega_{j} x_{j} / \sum_{j=1}^{5} h_{j} \omega_{j} \\
y=\sum_{j=1}^{5} h_{j} \omega_{j} y_{j} / \sum_{j=1}^{5} h_{j} \omega_{j}
\end{array}\right.
$$

It can be calculated that $\mathrm{x}=4.09, \mathrm{y}=6.32$;

The distance $d_{j}$ between the distribution center and the demand point is

$$
d_{j}=\sqrt{\left(x_{j}-\mathrm{a}\right)^{2}+\left(y_{j}-\mathrm{b}\right)^{2}}
$$

Then, the model of the total freight rate based on the centroid method is expressed as follows,

$$
H=\sum_{j=1}^{5} h_{j} \omega_{j} \sqrt{\left(x_{j}-\mathrm{a}\right)^{2}+\left(y_{j}-\mathrm{b}\right)^{2}}
$$

After calculation, the total freight $\mathrm{H}$ is 21387 yuan, and the coordinate of the final location point is $\mathrm{O}(4.09,6.32)$ The site selection point $\mathrm{O}$ is marked as shown in Figure 4.

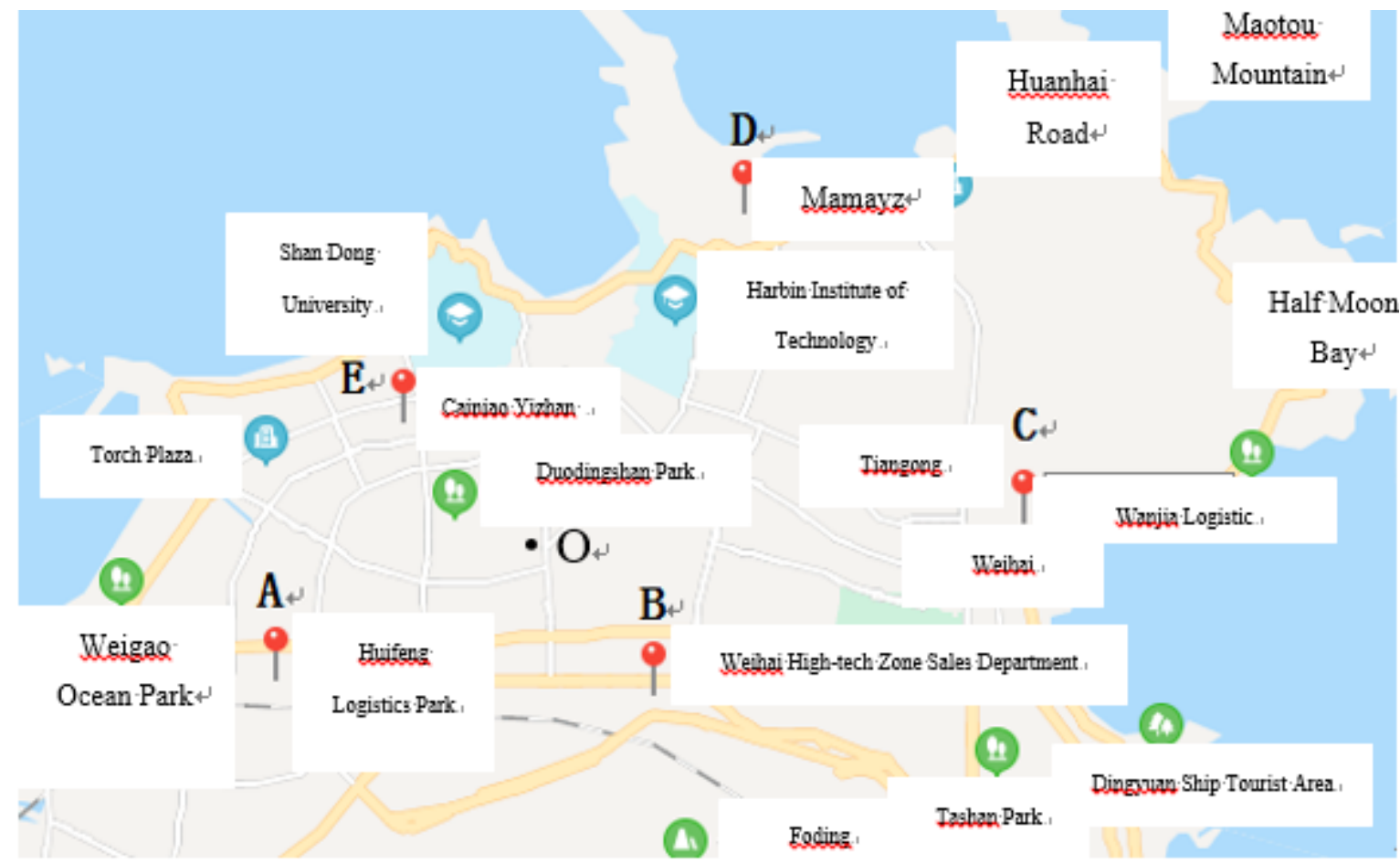

Fig 4:Location of the international logistics distribution center intended to be built in High-Tech Zone

\section{Location Evaluation of Weihai Port International Logistics Center Based on Fuzzy Evaluation Method}

3.1 Fuzzy comprehensive evaluation method model

ISSN: 0010-8189

(C) CONVERTER 2020

www.converter-magazine.info 
Suppose the evaluation index set is $U$ and there are m evaluation indexes, then:

$$
\mathrm{U}=\left(\mathrm{u}_{1}, \mathrm{u}_{2}, \mathrm{u}_{3}, \cdots, \mathrm{u}_{\mathrm{m}}\right)
$$

In the formula, $\mathrm{u}_{\mathrm{i}}$ is each evaluation index.

Suppose the comment set of the evaluation index is $\mathrm{V}$, and there are $\mathrm{n}$ evaluation orders, then there is an evaluation set:

$$
\mathrm{V}=\left(\mathrm{v}_{1}, \mathrm{v}_{2}, \mathrm{v}_{3}, \cdots, \mathrm{v}_{\mathrm{n}}\right)
$$

Then, the fuzzy relationship between the comment set $\mathrm{U}$ and the evaluation set $\mathrm{V}$ can be indicated by matrix $\mathrm{R}$ :

$$
\mathrm{R}=\left[\begin{array}{cccc}
\mathrm{r}_{11} & \mathrm{r}_{12} & \cdots & \mathrm{r}_{1 \mathrm{~m}} \\
\mathrm{r}_{21} & \mathrm{r}_{22} & \cdots & \mathrm{r}_{2 \mathrm{~m}} \\
\vdots & \vdots & \ddots & \vdots \\
\mathrm{r}_{\mathrm{n} 1} & \mathrm{r}_{\mathrm{n} 1} & \cdots & \mathrm{r}_{\mathrm{nm}}
\end{array}\right]
$$

Where, $r_{i j}$ represents the jth comment of the evaluation object corresponding to $u_{i}$. The $i$-th row in the matrix is the single-factor evaluation of the $\mathrm{i}$-th index $\mathrm{u}_{\mathrm{i}}$, which is a fuzzy subset of the comment domain $\mathrm{U}$, and there is the following relationship:

$$
\mathrm{r}_{\mathrm{ij}}=\mathrm{u}_{\mathrm{r}}\left(\mathrm{u}_{\mathrm{i}}, \mathrm{v}_{\mathrm{i}}\right)\left(0 \leq \mathrm{r}_{\mathrm{ij}} \leq 1\right)
$$

Regarding evaluation of the influence of multi-level factors, we analyze and consider the different attributes and different degrees of each individual factor in the process of summary and evaluation. The magnitude of its influence forms a fuzzy subset $A$ of the set $U, A=\left(a_{1}, a_{2}, \cdots, a_{n}\right)$. Where, $a_{i}$ is the degree of membership of $u_{i}$ to A. It means the degree of influence $u_{i}$ in the overall evaluation, which to some extent represents the ability to rank according to $\mathrm{u}_{\mathrm{i}}$ and is referred to as ability coefficient.

When A and R are known, perform fuzzy transformation to make a judgment:

$$
\left(b_{1}, b_{2}, b_{3}, \cdots, b_{n}\right)=\left(a_{1}, a_{2}, a_{3}, \cdots, a_{n}\right)\left[\begin{array}{cccc}
r_{11} & r_{12} & \cdots & r_{1 m} \\
r_{21} & r_{22} & \cdots & r_{2 m} \\
\vdots & \vdots & \ddots & \vdots \\
r_{n 1} & r_{n} & \cdots & r_{n m}
\end{array}\right]
$$

Where: $\mathrm{B}$ is the equivalent fuzzy subset on the evaluation set $\mathrm{V} ; \mathrm{b}_{\mathrm{j}}$ is the degree of membership of the level $\mathrm{V}_{\mathrm{i}}$ to the equivalent fuzzy subset $\mathrm{B}$ as a result of the comprehensive evaluation. To make a decision, according to the principle of maximum degree of membership, the level $V_{i}$ corresponding to the biggest $b_{i}$ is taken as the result of comprehensive evaluation.

\subsection{Evaluation and analysis of site selection results based on fuzzy comprehensive evaluation}

By comparing the three candidate locations in the urban area of Weihai, we make data analysis using fuzzy comprehensive evaluation method based on actual development status of Weihai Port, and the site selection is finally determined.

Location O: Near the intersection of Dalian Road and Dongtai Road, Weihai High-tech Development Zone (the proposed location for the International Logistics Distribution Center in Weihai High-Tech Zone). Reasons: The location has convenient transportation and obvious manpower advantage. There are various industrial, commercial, and residential areas in the surrounding area, and the service objects are abundant.The location of the facilities

ISSN: 0010-8189

(C) CONVERTER 2020

www.converter-magazine.info 
having direct or indirect trade relations with the seaport is relatively central in the High-Tech Zone, and the transportation cost is relatively reasonable.

Location P: No. 9 Huanshan Road, Weihai City (JiaxingYuntong International Logistics Park). Reasons: it is close to the port, cargo transportation costs are the lowest; modern information technology is developed, which benefits diversified logistics services.

Location Q: No. 1-11, Fuzhou Road, Industrial New District, Huancui District, Weihai City (Weihai International Logistics Park). Reasons: as the government bidding location, it has the advantage of policy support; as an important node of the transportation trunk line in the water front area, it facilitates goods transportation.

The specific locations of the above three sites on the map are shown in Figure 5.

proposed location in the high-tech zone Weihai International Logistics Park Weihai Port JiaxingYuntong International Logistics Park

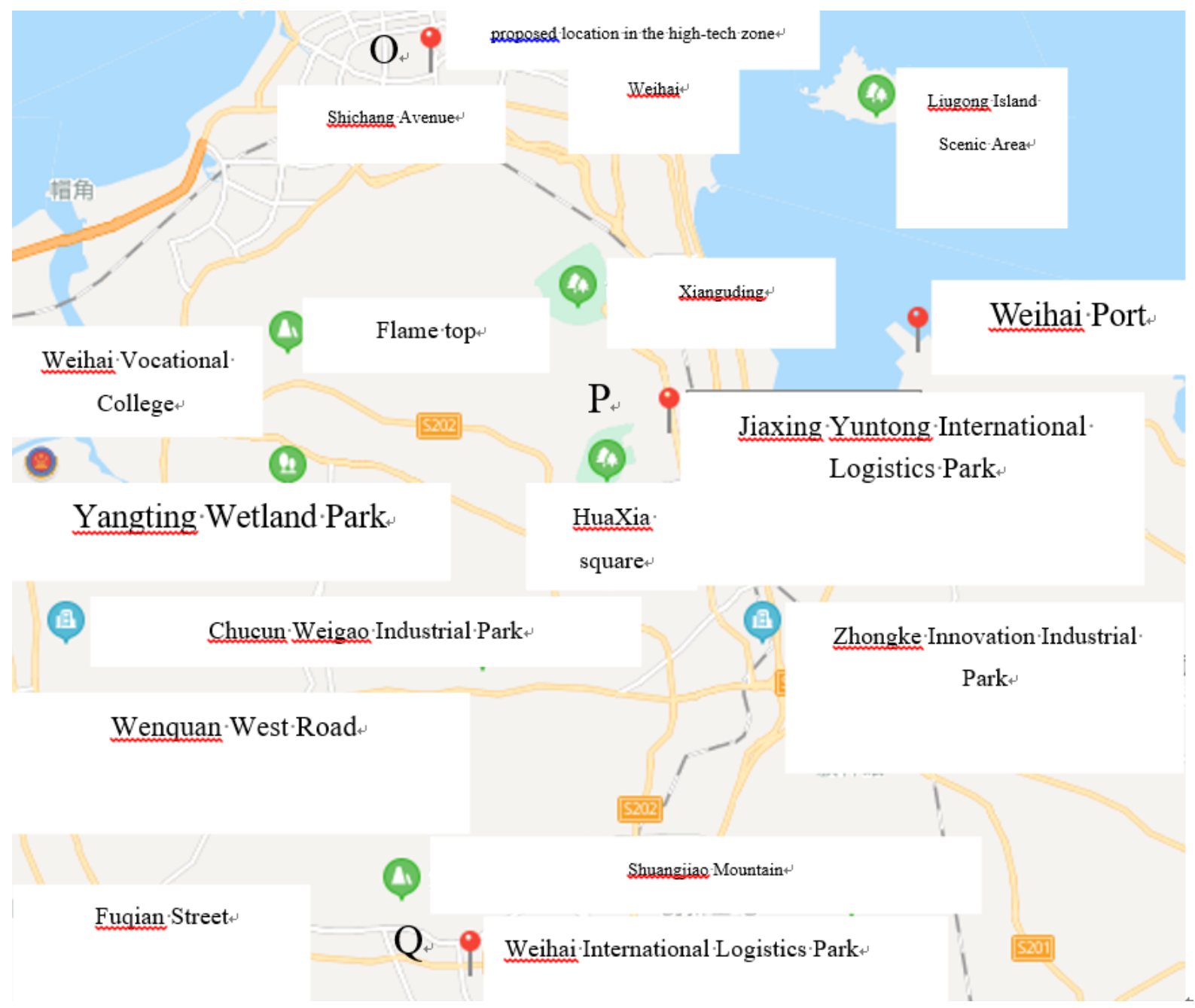

Fig 5: Alternative locations for Weihai Port International Logistics Center

By combining quantitative factors with qualitative factors, we comprehensively analyze the influencing factors and the weights of indexes at each level.The calculation method is as follows:

"Internal factors" and "external factors" are used as primary indexes, and the importance of "external factors" is 1.5

ISSN: 0010-8189

(C) CONVERTER 2020

www.converter-magazine.info 
times that of "internal factors". Record the correction coefficient (internal factor) as 1 , then the correction coefficient of "external factor" is 1.5 , and the sum of the correction coefficients is 2.5. After calculation, the final weights of "internal factors" and "external factors" are 0.4 and 0.6 respectively, as shown in Table 2 . The indexes and weights at each level are calculated and integrated as shown in Table 3.

Table 2 Weight analysis data table

\begin{tabular}{cccc}
\hline Primary index & Importance & Correction coefficient & Final weight \\
\hline Internal factor & - & 1.0 & 0.4 \\
external factor & 1.5 & 1.5 & 0.6 \\
total & - & 2.5 & 1.0 \\
\hline
\end{tabular}

Table 3 Comprehensive evaluation index and weight table

\begin{tabular}{|c|c|c|c|c|c|c|c|}
\hline Primary index & weight & Secondary index & weight & Primary index & weight & Secondary index & weight \\
\hline \multirow{4}{*}{ Internal factor } & \multirow{4}{*}{0.4} & Infrastructure & 0.4 & \multirow{4}{*}{ External factor } & \multirow{4}{*}{0.6} & $\begin{array}{c}\text { Transportation } \\
\text { cost }\end{array}$ & 0.4 \\
\hline & & $\begin{array}{c}\text { Management } \\
\text { quality }\end{array}$ & 0.2 & & & $\begin{array}{c}\text { Transportation } \\
\text { demand }\end{array}$ & 0.4 \\
\hline & & Service level & 0.3 & & & Market support & 0.1 \\
\hline & & $\begin{array}{c}\text { Modernization } \\
\text { level }\end{array}$ & 0.1 & & & Natural factor & 0.1 \\
\hline
\end{tabular}

Based on objective evaluation of the above three alternative sites through questionnaires, the scoring and evaluation results of each factor under the two primary indexes are shown in the appendix (Table A1).

From the comprehensive evaluation table, evaluation matrix of the internal factors in the primary indexes of location O can be obtained as follows:

$$
\mathrm{R}_{\text {Oin }}=\left[\begin{array}{llll}
0.4 & 0.3 & 0.2 & 0.1 \\
0.6 & 0.2 & 0.1 & 0.1 \\
0.3 & 0.3 & 0.3 & 0.1 \\
0.0 & 0.2 & 0.0 & 0.8
\end{array}\right]
$$

According to the weight of each index, the comprehensive evaluation regarding the internal factors in the primary index of location $\mathrm{O}$ is as follows:

$$
\mathrm{B}_{\text {Oin }}=\mathrm{A}_{\mathrm{Oex}} \mathrm{R}_{\mathrm{Oex}}=\left(\begin{array}{llll}
0.37 & 0.27 & 0.19 & 0.17
\end{array}\right)
$$

Where, $\mathrm{A}_{\text {Oin }}=\left(\begin{array}{llll}0.4 & 0.2 & 0.3 & 0.1\end{array}\right)$

In the same way, the comprehensive evaluation of internal factors of locations $\mathrm{P}$ and $\mathrm{Q}$ and external factors of locations $\mathrm{O}, \mathrm{P}$, and $\mathrm{Q}$ are as follows:

$$
\mathrm{B}_{\text {Pin }}=\mathrm{A}_{\text {Pin }} \mathrm{R}_{\text {Pin }}=\left(\begin{array}{llll}
0.53 & 0.22 & 0.17 & 0.08
\end{array}\right)
$$

ISSN: 0010-8189

(C) CONVERTER 2020 


$$
\begin{aligned}
\mathrm{B}_{\text {Qin }} & =\mathrm{A}_{\text {Qin }} \mathrm{R}_{\text {Qin }}=\left(\begin{array}{llll}
0.14 & 0.44 & 0.32 & 0.10
\end{array}\right) \\
\mathrm{B}_{\text {Oex }} & =\mathrm{A}_{\text {Oex }} \mathrm{R}_{\text {Oex }}=\left(\begin{array}{llll}
0.10 & 0.35 & 0.23 & 0.32
\end{array}\right) \\
\mathrm{B}_{\text {Pex }} & =\mathrm{A}_{\text {Pex }} \mathrm{R}_{\text {Pex }}=\left(\begin{array}{llll}
0.70 & 0.23 & 0.07 & 0.00
\end{array}\right) \\
\mathrm{B}_{\text {Qex }} & =\mathrm{A}_{\text {Qex }} \mathrm{R}_{\text {Qex }}=\left(\begin{array}{llll}
0.12 & 0.18 & 0.52 & 0.18
\end{array}\right)
\end{aligned}
$$

In view of the above, comprehensive evaluation data of secondary indexes can be obtained, see the appendix (Table A2) for details. According to the weights of the indexes at all levels, comprehensive evaluation of the primary indexes for the three alternative sites is obtainedbased on calculation as follows:

$$
\begin{aligned}
& \mathrm{B}_{\mathrm{O}}=\left(\begin{array}{llll}
0.208 & 0.318 & 0.214 & 0.260
\end{array}\right) \\
& \mathrm{B}_{\mathrm{P}}=\left(\begin{array}{llll}
0.632 & 0.226 & 0.110 & 0.032
\end{array}\right) \\
& \mathrm{B}_{\mathrm{Q}}=\left(\begin{array}{llll}
0.128 & 0.284 & 0.440 & 0.148
\end{array}\right)
\end{aligned}
$$

To select the optimal site among the three locations, the weights 4, 3, 2, and 1 are assigned to excellent, good, fair, and poor in the questionnaire comments. After weighting, scores of the three locations are 2.474, 3.458, and 2.392, respectively. By comparing the above values, location $\mathrm{P}$ is finally selected, that is, the most suitable location for the Weihai Port International Logistics Distribution Center is near No. 9 Huanshan Road, Weihai City (JiaxingYuntong International Logistics Park).

\section{Conclusion Analysis}

Actual evaluation and analysis shows that the coordinates of the site selected based on centroid method are slightly different from the actual optimal site according to the fuzzy comprehensive evaluation method. It avoids the shortcomings of centroid method in ideal model site selection, and adapts more to the actual economic status of Weihai Port and hinterland, which shows certain rationality [7-8]. For location P, after data collection and analysis, a linear regression analysis is made on business volume of the final location (Jiaxing Yuntong International Logistics Park), and the business volume trend forecast for the next two years is shown in Figure 6.

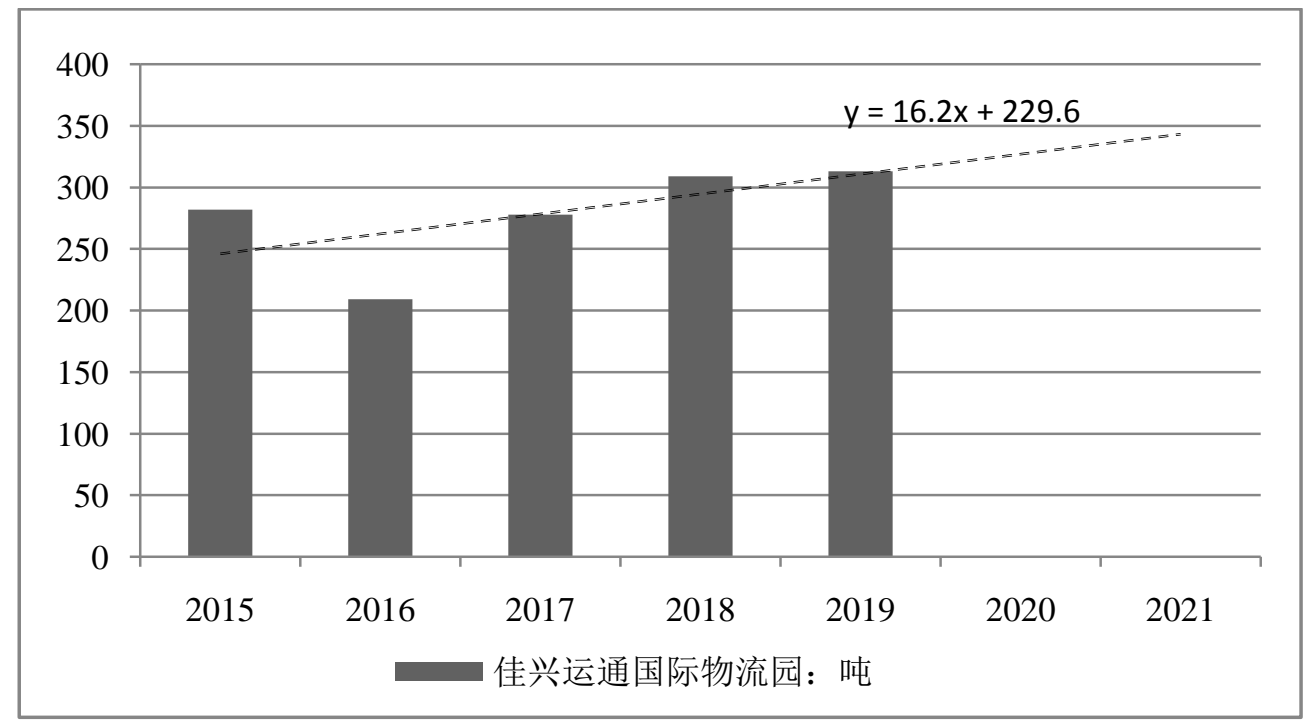

Note: The independent variable $\mathrm{x}$ of the regression equation is the xth year, 2015 is the first year, and so on.

Fig 6:Linear regression analysis of the business volume of Jiaxing Yuntong International Logistics Park

Calculated by linear regression equation, the predicted business volume of location P in 2020 and 2021 is 3.268 million tons and 3.43 million tons, respectively. From the above, it can be seen that JiaxingYuntong International Logistics Park currently enjoys sound development. The logistics park has a big demand for the domestic and foreign transportation markets and Weihai Port, so it is appropriate to set up a cargo distribution center here. In addition, $\mathrm{P}$ is

ISSN: 0010-8189

(C) CONVERTER 2020

www.converter-magazine.info 
located in the center of many port cargo transportation service companies. Establishment of a port logistics distribution center here will not only promote the import and export goods transportation in Weihai Port, but also greatly impact goods classification and value-added services. Meanwhile, it will help achieve the economic development goals of Weihai New Port Area, realize rational allocation of resources, boost employment of surrounding residents, and improve people's living standards, which will stimulateWeihai's economic growth and advance a new round of development inWeihai's international logistics industry.

\section{References}

[1] T. X. Zhang, C. B. Chen,"Research on Cluster Analysis of Logistics Development Level in Guangxi,”Logistics Sci-tech, no. 5, pp. 129-133, 2020.

[2] H. Y. Dong, "Study on comprehensive evaluation of regional logistics development in Sichuan province"Logistics Sci-Tech, no.7, pp. 11-15, 2010.

[3] B. Wang, T. J. Yang, Y. B. Zhao, "Comprehensive evaluation of regional logistics development,'Industrial Engineering Journal,no.1, pp. 83-87, 2005.

[4] G. Ding, S. Y. Jin, Z. Q Huang,"On the regional spatial diversity of the economic development transformation mode of Fujian Province,"Journal Of Changchun Institute Of Technology(Social Science Edition), no. 3, pp. 35-38, 2010.

[5] B. Z. Zhu, J. Li, "Comprehensive evaluation of regional logistics development level Based on principal component analysis_ taking Jiangmen city, Guangdong province as an example,"'Industrial Technology \& Economy, no. 5, pp. 105-107, 2008.

[6] B. Eleonora, "Improving logistics efficiency of industrial districts:a framework and case study in the food sector,"International Journal of Logistics Research and Applications, no. 5, pp. 402-403, 2015.

[7] D. Mu, Z. Du, "DEA analysis of reverse logistics of supply chain integration project choice,"Journal of Systems Science and Information, no. 2, pp. 23-330, 2006.

[8] B. Z. Zhu, J. Li, "Comprehensive evaluation of regional logistics development level based on principal component analysis— taking Jiangmen city, Guangdong province as an example,"Industrial Technology \& Economy, no. 5, pp. 105-107, 2008.

\section{Appendix}

Table A1 Questionnaire evaluation scoring statistics table

\begin{tabular}{|c|c|c|c|c|c|}
\hline $\begin{array}{l}\text { Internal } \\
\text { Factor }\end{array}$ & Score & Excellent & Good & Fair & Poor \\
\hline \multirow{8}{*}{ Location $\mathrm{O}$} & Infrastructure & 0.4 & 0.3 & 0.2 & 0.1 \\
\hline & $\begin{array}{l}\text { Management } \\
\text { quality }\end{array}$ & 0.6 & 0.2 & 0.1 & 0.1 \\
\hline & Service level & 0.3 & 0.3 & 0.3 & 0.1 \\
\hline & $\begin{array}{c}\text { Modernization } \\
\text { level }\end{array}$ & 0.0 & 0.2 & 0.0 & 0.8 \\
\hline & $\begin{array}{c}\text { Transportation } \\
\text { cost }\end{array}$ & 0.2 & 0.6 & 0.1 & 0.1 \\
\hline & $\begin{array}{l}\text { Transportation } \\
\text { demand }\end{array}$ & 0.0 & 0.1 & 0.3 & 0.6 \\
\hline & Market support & 0.1 & 0.2 & 0.5 & 0.2 \\
\hline & Natural factor & 0.1 & 0.5 & 0.2 & 0.2 \\
\hline \multirow[b]{2}{*}{ Location P } & Infrastructure & 0.2 & 0.4 & 0.3 & 0.1 \\
\hline & $\begin{array}{l}\text { Management } \\
\text { quality }\end{array}$ & 0.8 & 0.1 & 0.05 & 0.05 \\
\hline
\end{tabular}

ISSN: 0010-8189

(c) CONVERTER 2020 


\begin{tabular}{|c|c|c|c|c|c|}
\hline & Service level & 0.7 & 0.1 & 0.1 & 0.1 \\
\hline & $\begin{array}{l}\text { Modernization } \\
\text { level }\end{array}$ & 0.8 & 0.1 & 0.1 & 0.0 \\
\hline & $\begin{array}{c}\text { Transportation } \\
\text { cost }\end{array}$ & 0.7 & 0.2 & 0.1 & 0.0 \\
\hline & $\begin{array}{c}\text { Transportation } \\
\text { demand }\end{array}$ & 0.8 & 0.2 & 0.0 & 0.0 \\
\hline & Market support & 0.5 & 0.4 & 0.1 & 0.0 \\
\hline & Natural factor & 0.5 & 0.3 & 0.2 & 0.0 \\
\hline \multirow{8}{*}{ Location Q } & Infrastructure & 0.2 & 0.4 & 0.3 & 0.1 \\
\hline & $\begin{array}{c}\text { Management } \\
\text { quality }\end{array}$ & 0.1 & 0.5 & 0.3 & 0.1 \\
\hline & Service level & 0.1 & 0.5 & 0.3 & 0.1 \\
\hline & $\begin{array}{l}\text { Modernization } \\
\text { level }\end{array}$ & 0.1 & 0.3 & 0.5 & 0.1 \\
\hline & $\begin{array}{c}\text { Transportation } \\
\text { cost }\end{array}$ & 0.2 & 0.1 & 0.6 & 0.1 \\
\hline & $\begin{array}{c}\text { Transportation } \\
\text { demand }\end{array}$ & 0.0 & 0.1 & 0.6 & 0.3 \\
\hline & Market support & 0.2 & 0.5 & 0.2 & 0.1 \\
\hline & Natural factor & 0.2 & 0.5 & 0.2 & 0.1 \\
\hline
\end{tabular}

Table A2 Evaluation data table of secondary indexes

\begin{tabular}{|c|c|c|c|c|c|}
\hline Factor & Score & Excellent & Good & Fair & Poor \\
\hline \multirow{2}{*}{ Location $\mathrm{O}$} & $\begin{array}{l}\text { Internal } \\
\text { factor }\end{array}$ & 0.37 & 0.27 & 0.19 & 0.17 \\
\hline & $\begin{array}{l}\text { External } \\
\text { factor }\end{array}$ & 0.10 & 0.35 & 0.23 & 0.32 \\
\hline \multirow{2}{*}{ Location P } & $\begin{array}{l}\text { Internal } \\
\text { factor }\end{array}$ & 0.53 & 0.22 & 0.17 & 0.08 \\
\hline & $\begin{array}{l}\text { External } \\
\text { factor }\end{array}$ & 0.70 & 0.23 & 0.07 & 0.00 \\
\hline \multirow{2}{*}{ Location Q } & $\begin{array}{l}\text { Internal } \\
\text { factor }\end{array}$ & 0.14 & 0.44 & 0.32 & 0.10 \\
\hline & $\begin{array}{l}\text { External } \\
\text { factor }\end{array}$ & 0.12 & 0.18 & 0.52 & 0.18 \\
\hline
\end{tabular}

